NBER WORKING PAPER SERIES

\title{
DISTRIBUTIONAL EFFECTS OF MONETARY POLICY IN EMERGING MARKET ECONOMIES
}

\author{
Eswar Prasad \\ Boyang Zhang \\ Working Paper 21471 \\ http://www.nber.org/papers/w21471
NATIONAL BUREAU OF ECONOMIC RESEARCH
1050 Massachusetts Avenue
Cambridge, MA 02138

August 2015

\begin{abstract}
We are grateful for comments provided by participants at the Royal Economic Society Annual Conference, IMF-DFID Conference on "Macroeconomic Challenges Facing Low-Income Countries", CEP-Federal Reserve Bank of Atlanta Workshop on Monetary Policy and Inequality, the China Meeting of the Econometric Society, the Midwest Economic Theory and Trade Conference, and other workshops and seminars. Edward Buffie, Gita Gopinath, and other colleagues provided helpful comments and suggestions. The views expressed herein are those of the authors and do not necessarily reflect the views of the National Bureau of Economic Research.
\end{abstract}

NBER working papers are circulated for discussion and comment purposes. They have not been peerreviewed or been subject to the review by the NBER Board of Directors that accompanies official NBER publications.

(C) 2015 by Eswar Prasad and Boyang Zhang. All rights reserved. Short sections of text, not to exceed two paragraphs, may be quoted without explicit permission provided that full credit, including (C) notice, is given to the source. 
Distributional Effects of Monetary Policy in Emerging Market Economies

Eswar Prasad and Boyang Zhang

NBER Working Paper No. 21471

August 2015

JEL No. E25,E52,E58,F41

\title{
$\underline{\text { ABSTRACT }}$
}

We develop a two-sector, heterogeneous-agent model with incomplete financial markets to study the distributional effects and aggregate welfare implications of alternative monetary policy rules in emerging market economies. Relative to inflation targeting, exchange rate management benefits households in the tradable goods sector but in the long run these households are worse off due to higher consumption volatility. A fixed exchange rate reduces the welfare of these households and aggregate welfare when the economy is hit by positive shocks to nontradable goods productivity or foreign interest rates. Fiscal policy can more efficiently achieve similar short-run distributional objectives as exchange rate management.

\author{
Eswar Prasad \\ Dyson School of Applied Economics and \\ Management \\ Cornell University \\ 301A Warren Hall \\ Ithaca, NY 14853 \\ and NBER \\ eswar.prasad@cornell.edu \\ Boyang Zhang \\ Department of Economics \\ Cornell University \\ Ithaca, NY, 14853 \\ bz95@cornell.edu
}




\section{Introduction}

Monetary policy analysis for emerging market economies has traditionally been conducted with open economy extensions of models that are mainly relevant for advanced economies. Emerging market economies have a number of structural features that cannot easily be captured by minor variations of such models. Features that are typical to these economies include incomplete and underdeveloped financial markets, low levels of financial access, and weak monetary transmission mechanisms. These factors make the effectiveness of monetary policy and even its effects on real and nominal variables harder to discern in conventional theoretical settings.

An additional dimension that has only recently started getting attention in academic circles concerns the distributional consequences of monetary policy. While there is a lively debate about the magnitude of these effects in advanced economies, distributional consequences of monetary policy are likely to be of first-order importance in emerging market economies, given their underdeveloped financial systems. Incomplete financial markets, coupled with insufficient access to formal financial institutions, limit households' ability to insure against household-specific or sector-specific shocks and magnify the distributional effects of aggregate macroeconomic fluctuations.

In this paper, we develop a theoretical model that allows us to simultaneously evaluate the aggregate and distributional effects of different monetary policy rules in a small open economy setting. The features that we incorporate into the model make it especially relevant for the analysis of monetary policy in emerging market economies. The main features include heterogeneous households, incomplete financial markets, and two sectors-tradable and nontradable goods. While tradable goods prices are set in international markets, nontradable goods prices are sticky. ${ }^{1}$

To motivate our analysis, we focus on a specific contemporary policy issue that central

\footnotetext{
${ }^{1}$ Although our analysis focuses on middle-income emerging market economies, the features noted here and the results in the paper apply equally, if not more forcefully, to low-income developing economies.
} 
bankers in emerging market economies face, that is, nominal exchange rate management. While many of these economies have chosen to abandon fixed exchange rate regimes, the level and volatility of nominal exchange rates are still a major concern for their central bankers. Emerging markets often face sharp exchange rate volatility in the short run due to shocks to their terms of trade, productivity, and, more recently, the impact of unconventional monetary policy actions of advanced economy central banks.

As a result, central bankers in emerging market economies, fearful of exchange rate overshooting in the short run and the effects this could have on the competitiveness of their exports, have attempted to limit nominal exchange rate appreciation. Many of them adopt a policy of "leaning against the wind" to limit what they view as excessive exchange rate volatility but otherwise not actively resisting currency appreciation (or depreciation). Some countries have also tried to delay real exchange rate appreciation in order to protect the export competitiveness of their tradable goods sectors.

This policy choice has significant distributional consequences, particularly on account of financial frictions and household heterogeneity in emerging market economies. When the interests of households in the tradable goods sector are given prominence-perhaps for political economy reasons related to protecting jobs in that sector-a policy attempting to keep the nominal exchange rate stable can in principle help stabilize relative prices and increase the welfare of workers in this sector. However, this policy tends to be more tolerant of inflation and can have negative consequences for workers in the nontradable goods sector and could even reduce aggregate welfare.

We find that nominal exchange rate management in response to productivity shocks in the tradable goods sector does indeed improve the short-run welfare of households in that sector. But this comes at the expense of the welfare of households in the nontradable goods sector. Interestingly, we find that these welfare effects are reversed in the long run. Nominal exchange rate management increases the volatility of tradable goods households' consumption, reducing their long-run welfare. Moreover, when the central bank attempts to 
stabilize the nominal exchange rate in response to other shocks-such as productivity shocks in the nontradable goods sector or foreign interest rate shocks-the welfare of households in the tradable goods sector and aggregate welfare are negatively affected both in the short run and in the long run.

Extended versions of the model enable us to consider the effects of different monetary policy rules against the background of a broader range of other policy settings. In the presence of capital controls, exchange rate management can deliver even sharper shortrun consumption benefits to households in the tradable goods sector relative to inflation targeting. But long-run welfare costs for these households also rise on account of higher consumption volatility. Flexible inflation targeting, which incorporates a measure of the output gap in the monetary policy rule, leads to similar results. We also find that fiscal policy, through a set of targeted taxes and transfers, can more efficiently achieve similar distributional effects as exchange rate management.

\subsection{Related literature}

Our work builds upon three existing strands of research: distributional effects of monetary policy in advanced economies; heterogeneous agent models; and the new open economy macroeconomics.

Interest in the distributional effects of U.S. monetary policy has been revived by a handful of important new papers. In an early contribution, Romer and Romer (1999) examine the effects of inflation on the poor. They document that inflation and macroeconomic instability are correlated with increases in inequality. Erosa and Ventura (2002), Doepke and Schneider (2006), Meh and Terajima (2011), and Doepke, Schneider, and Selezneva (2015) analyze the channels through which inflation affects distribution. Coibion et al. (2012) argue that contractionary monetary policy increases inequality through two other channels-wage distribution and financial income. Gornemann, Kuester, and Nakajima (2014) find that accommodative monetary policy benefits "Main Street" at the expense of "Wall Street" in 
large downturns, but on average the effect is the opposite. Brunnermeier and Sannikov (2012) tackle the issue from the aspect of financial institutions and show how monetary policy has distributional effects by affecting interest rates and the yield curve. ${ }^{2}$ Meh, Ríos-Rull, and Terajima (2010) show how inflation targeting and price-level targeting can have very different distributional consequences.

In order to study distributional effects, heterogeneity across households is an important feature that needs to be included in our model. One approach is to introduce idiosyncratic labor income shocks as in Krusell and Smith (1998). Alternative approaches to modeling heterogeneity include the assumption of differential access to financial markets, as in Galí, López-Salido, and Vallés (2004). Recent progress in examining the distributional effects of fiscal and monetary policies using heterogeneous-agent models can be found in McKay and Reis (2015) and Gornemann, Kuester, and Nakajima (2014).

The two strands of literature discussed above mainly focus on closed economies in theoretical work and on the U.S. and other advanced economies in empirical work. Our contribution is to extend this work to a small open economy setting relevant for emerging markets and to assess both the distributional and aggregate effects of different monetary and exchange rate policies in such economies.

The new open economy macroeconomics literature serves as our modeling foundation. Recent examples of the dynamic stochastic general equilibrium (DSGE) framework we employ in the paper can be found in Clarida, Galí, and Gertler (2002). ${ }^{3}$ In particular, we adapt the modeling framework of Galí and Monacelli (2005, 2008), who develop a small open economy model with nominal rigidities. Engel (2011) shows that optimal policy needs to target CPI inflation, the output gap, and currency misalignment. The instrument rule derived in that setup does not include either the output gap or the measure of currency misalignment. In a small open economy setting, Kollmann (2002) and Leitemo and Söderström (2005) conclude

\footnotetext{
${ }^{2}$ In related work, Bell et al. (2012) examine the distributional effects of asset purchases by central banks. Korinek and Kreamer (2014) study the redistributive effects of financial deregulation.

${ }^{3}$ Other important early papers in this literature that we build upon include Benigno and Benigno (2003), Devereux and Engel (2003), Benigno (2004), Corsetti and Pesenti (2005), and Sutherland (2005).
} 
that there is no welfare gain from augmenting the monetary policy reaction function with an exchange rate variable. However, there is considerable evidence that, in practice, emerging markets do incorporate exchange rate considerations in their monetary policy formulation. For instance, Mohanty and Klau (2005) find that, in most emerging market economies, the interest rate responds strongly to the exchange rate. Frömmel, Garabedian, and Schobert (2011) document that central banks in Eastern Europe respond to exchange rate fluctuations. The same result holds even for advanced but highly open economies. Lubik and Schorfheide (2007) conclude that the Bank of Canada and the Bank of England take account of the nominal exchange rate in their policy reactions.

Another important strand within the new open economy macroeconomics literature is the work on emerging market economies. For instance, Aguiar and Gopinath (2007) suggest that emerging market economies face large nonstationary productivity shocks so that growth trend fluctuations constitute their business cycles. García-Cicco, Pancrazi, and Uribe (2010) use a small open economy with financial frictions to characterize business cycles in emerging markets. Devereux, Lane, and Xu (2006) compare alternative monetary policies with high and low exchange rate pass-through. Liu and Spiegel (2015) study optimal monetary policy and capital account restrictions in a small open economy.

Both of these strands of existing literature on open economies have tended to focus on aggregate welfare effects rather than distributional consequences. Our contribution relative to this literature is to study distributional effects rather than just aggregate welfare consequences of monetary policy. This highlights a key point of departure of our modeling framework compared to the literature cited above-the presence of financial frictions. Financial market incompleteness is crucial to generate distributional effects. The interaction between nominal rigidities and financial frictions plays a key role in our modeling framework. ${ }^{4}$

\footnotetext{
${ }^{4}$ In recent work that is related to ours, Anand, Prasad, and Zhang (2015) develop a DSGE model that features a food sector and incomplete financial markets to determine what measure of inflation a developing economy central bank should target.
} 


\section{Model}

In this section, we develop a small open economy model incorporating features that are relevant for emerging market economies and use it to study the distributional effects of alternative monetary policy rules. We sketch the main features of the model here, with a more detailed listing of the model equations consigned to Appendix 1.

\subsection{Households}

The economy consists of a continuum of infinitely-lived households of two types: (i) measure $\lambda>0$ of households working in the tradable goods sector, and (ii) measure $1-\lambda$ of households working in the nontradable goods sector. Prices of tradable goods are flexible and set in the foreign currency, determined in international markets, and taken as given from the home economy's point of view. Prices of nontradable goods are set by monopolistically competitive firms, denominated in the domestic currency, and sticky.

We assume that labor is immobile across the tradable and nontradable goods sectors. ${ }^{5}$ The representative household, denoted by the superscript $i$, is indexed by $T$ (tradable sector) and $N$ (nontradable sector). Household $i$ maximizes the discounted stream of utility:

$$
\max E_{0} \sum_{t=0}^{\infty} \beta^{t}\left[U\left(C_{t}^{i}, L_{t}^{i}\right)\right]
$$

where $\beta \in(0,1)$ is the discount factor, $C_{t}^{i}$ is the composite consumption index of household $i$ in period $t$, including tradable and nontradable goods, and $L_{t}^{i}$ is the labor supplied by household $i$. The utility function takes the form:

\footnotetext{
${ }^{5}$ This assumption reflects the large inter-sectoral wage differentials in emerging market economies. Artuç, Lederman, and Porto (2013) present estimates of labor mobility costs in developing countries and document that the costs of adjustment to trade shocks are high in these economies, restricting inter-sectoral labor mobility. Lee and Wolpin (2006) find that, even in advanced economies, there are large costs for labor to move across sectors.
} 


$$
U\left(C_{t}^{i}, L_{t}^{i}\right)=\frac{C_{t}^{i^{1-\sigma}}}{1-\sigma}-\phi_{i} \frac{L_{t}^{i^{1+\psi}}}{1+\psi}, \quad i \in\{T, N\}
$$

where $\sigma$ is the risk aversion coefficient, the parameter $\psi$ is the inverse of the Frisch elasticity, and $\phi_{i}$ is the scaling factor. The consumption index is defined as

$$
C_{t}^{i}=\left[b^{\frac{1}{\xi}}\left(C_{T, t}^{i}\right)^{\frac{\xi-1}{\xi}}+(1-b)^{\frac{1}{\xi}}\left(C_{N, t}^{i}\right)^{\frac{\xi-1}{\xi}}\right]^{\frac{\xi}{\xi-1}}
$$

where $C_{T, t}^{i}$ represents tradable goods and $C_{N, t}^{i}$ represents nontradable goods. The elasticity of substitution between tradable and nontradable goods is given by $\xi \in(0,+\infty)$ and $b \in$ $(0,1)$ is the weight on tradable goods in the consumption index. The composite tradable good $C_{T, t}^{i}$ comprises both domestically produced and imported tradable goods $\left(C_{H, t}^{i}\right.$ and $C_{F, t}^{i}$, respectively) and is given by

$$
C_{T, t}^{i}=\left[a^{\frac{1}{\eta}}\left(C_{H, t}^{i}\right)^{\frac{\eta-1}{\eta}}+(1-a)^{\frac{1}{\eta}}\left(C_{F, t}^{i}\right)^{\frac{\eta-1}{\eta}}\right]^{\frac{\eta}{\eta-1}}
$$

The parameter $a \in(0,1)$ denotes the share of domestically produced goods in the tradable goods consumption index, and $\eta \in(0,+\infty)$ is the elasticity of substitution between domestically produced and imported tradable goods. The composite nontradable good $C_{N, t}^{i}$ is a continuum of differentiated goods, given by

$$
C_{N, t}^{i}=\left[\int_{0}^{1} C_{N, t}^{i}(j)^{\frac{\varepsilon-1}{\varepsilon}} d j\right]^{\frac{\varepsilon}{\varepsilon-1}}
$$

The parameter $\varepsilon>1$ represents the elasticity of substitution between any two differentiated nontradable goods.

\subsection{Budget constraints and financial markets}

This section highlights the key difference between our model and those of previous authors who have studied monetary policy. With complete financial markets, heterogeneous house- 
holds can share risk arising from sector-specific shocks (or shocks that have asymmetric effects across sectors), implying that monetary policy has no distributional consequences. This assumption is unrealistic in the context of emerging market economies, where financial frictions are pervasive and a large share of households do not have access to formal financial markets. $^{6}$

Since most of these households work in the informal sector that mainly produces nontradable goods, we assume that households working in this sector lack access to financial markets and simply consume their wage income in each period. So these households are akin to "rule of thumb" consumers. ${ }^{7}$ A representative household in the nontradable sector maximizes its lifetime utility given by equation (1) subject to the budget constraint:

$$
P_{t} C_{t}^{N}=W_{N, t} L_{t}^{N}+\Pi_{N, t}
$$

where the right hand side is the total value of output in the nontradable goods sector. $W_{N, t}$ is the nominal wage in the nontradable goods sector and $\Pi_{N, t}$ represents profits earned by firms in this sector. The total expenditure needed to attain a consumption index $C_{t}^{N}$ is given by $P_{t} C_{t}^{N}$ where $P_{t}$ is defined as

$$
P_{t}=\left[b P_{T, t}^{1-\xi}+(1-b) P_{N, t}^{1-\xi}\right]^{\frac{1}{1-\xi}}
$$

$P_{T, t}$ denotes the price of tradable goods and is given by

$$
P_{T, t}=\left[a P_{H, t}^{1-\eta}+(1-a) P_{F, t}^{1-\eta}\right]^{\frac{1}{1-\eta}}
$$

$P_{N, t}$, the price index of nontradable goods, is defined as

\footnotetext{
${ }^{6}$ Demirgüç-Kunt and Klapper (2012) find that a majority of households in most emerging market economies lacks access to the formal financial system. By contrast, in advanced economies nearly all households have such access.

${ }^{7}$ As discussed below, there is no physical capital in the model and no alternative storage technology either that would allow for intertemporal consumption smoothing by households that have no access to financial markets.
} 


$$
P_{N, t}=\left[\int_{0}^{1} P_{N, t}(j)^{1-\varepsilon} d j\right]^{\frac{1}{1-\varepsilon}}
$$

Households in the tradable goods sector receive labor income and can buy one-period nominal bonds and foreign bonds to smooth their consumption. A representative household in this sector maximizes lifetime utility given by equation (1) subject to the following budget constraint

$$
P_{t} C_{t}^{T}+B_{t}+e_{t} B_{t}^{*}+\frac{\psi_{B}}{2} B_{t}^{* 2} \leq W_{T, t} L_{t}^{T}+R_{t-1} B_{t-1}+e_{t} R_{t-1}^{*} B_{t-1}^{*}
$$

where $B_{t}$ and $B_{t}^{*}$ represents the quantity of one-period nominal risk-free discount bonds denominated in domestic and foreign currencies, respectively. The nominal exchange rate is denoted by $e_{t}$ and the gross nominal interest rates for the two types of bonds are denoted by $R_{t}$ and $R_{t}^{*}$, respectively. ${ }^{8} W_{T, t}$ is the nominal wage in the tradable goods sector and $L_{t}^{T}$ is the labor supply in this sector.

\subsection{Production}

Firms in the tradable goods sector use a linear technology in labor $Y_{H, t}=A_{H, t} L_{t}^{T}$, subject to a common productivity shock $A_{H, t}$. Firms in this sector are price takers. Import prices are exogenous and follow the law of one price. The terms of trade, which links import and export prices, determines the export price. Thus, $P_{H, t}=S_{t} P_{F, t}$, where $S_{t}$ is the terms of trade. The zero profit condition then determines labor demand and wages.

Similarly, firms in the nontradable goods sector use a linear technology in labor $Y_{N, t}(j)=$ $A_{N, t} L_{t}^{N}(j)$ and are subject to a common productivity shock $A_{N, t}$. Following Calvo (1983), we assume that a fraction $\theta \in(0,1)$ of firms cannot change their price in each period. The remaining firms choose the optimal reset price to maximize their discounted future profits:

\footnotetext{
${ }^{8}$ We also include a small quadratic portfolio holding cost for foreign bond holdings, as suggested by Schmitt-Grohé and Uribe (2003), only to induce stationarity.
} 


$$
\max _{P_{N, t}(j)} E_{t} \sum_{s=0}^{\infty}\left\{(\beta \theta)^{s}\left(\frac{C_{t+s}^{N-\sigma}}{P_{t+s}}\right)\left[P_{N, t}(j)-M C_{N, t+s}\right] Y_{N, t+s}(j)\right\}
$$

where $M C$ denotes the marginal cost of production in nominal terms.

\subsection{Monetary policy}

We define aggregate inflation as $\pi_{t}=P_{t} / P_{t-1}$, inflation in the nontradable goods sector as $\pi_{N, t}=P_{N, t} / P_{N, t-1}$, and tradable goods sector inflation as $\pi_{T, t}=P_{T, t} / P_{T, t-1}$. The steady state is characterized by constant prices (zero inflation) and no price stickiness in the economy.

The central bank sets the short-term nominal interest rate $R_{t}$ according to a simple inflation targeting rule, with a possible additional response to exchange rate fluctuations (see, e.g., Lubik and Schorfheide, 2007):

$$
\log \left(\frac{R_{t}}{\bar{R}}\right)=\rho \log \left(\frac{R_{t-1}}{\bar{R}}\right)+(1-\rho)\left[\phi_{\pi} \log \left(\frac{\pi_{t}}{\bar{\pi}}\right)+\phi_{e} \log \left(\frac{e_{t}}{e_{t-1}}\right)\right]
$$

where $\bar{\pi}$ and $\bar{R}$ are the steady state values of inflation and the nominal interest rate, respectively. The term $\rho$ represents the central banker's preference for interest rate smoothing. ${ }^{9}$ $\phi_{\pi}$ and $\phi_{e}$ are the weights assigned by the central banker to the deviations of inflation from its steady state level and to the fluctuations of the nominal exchange rate. ${ }^{10}$ Setting the parameter $\phi_{e}$ to zero implies a pure inflation targeting regime, wherein the central banker is not concerned about the level of the exchange rate except insofar as it affects inflation. We set inflation targeting as the benchmark rule and then conduct policy experiments to study

\footnotetext{
${ }^{9}$ Interest rate smoothing behavior by central banks and its benefits are well documented (Clarida, Galí, and Gertler, 1998). Mohanty and Klau (2005) find that emerging market central banks also put substantial weight on interest rate smoothing. The formulation of the monetary policy rule with interest rate smoothing is similar to that used by Clarida, Galí, and Gertler (1999).

${ }^{10}$ Technically, one could also write down a policy rule that includes the deviation of the exchange rate from its steady state level rather than changes in the level of the exchange rate. However, this would be harder to interpret and operationalize in an environment where nominal and real shocks can continuously affect the steady state level of the nominal exchange rate. The formulation in equation (12) is in line with the stated objective of many emerging market central banks that describe their policy as "leaning against the wind" to limit sharp short-run exchange rate volatility. In any event, the results were qualitatively similar when we used deviations of the nominal exchange rate from its steady state level in the policy rule.
} 
the distributional effects of alternative monetary policy rules that put different weights on the exchange rate.

\subsection{Exogenous shock process}

We assume that productivity shocks in the tradable and nontradable goods sectors follow $\mathrm{AR}(1)$ processes. Firms in the export sector are subject to terms of trade shocks as they are price takers and face international market prices that are determined exogenously. The small open economy may also face foreign interest rate shocks. To sum up, there are four shocks in the model, with innovations to each of them drawn from i.i.d. normal distributions:

Productivity shock, tradable goods: $\quad \log \left(\frac{A_{H, t}}{\bar{A}_{H}}\right)=\rho_{a}^{H} \log \left(\frac{A_{H, t-1}}{\bar{A}_{H}}\right)+\varepsilon_{t}^{H}, \quad \varepsilon_{t}^{H} \sim N\left(0, \sigma_{a}^{H}\right)$

Productivity shock, nontradable goods: $\log \left(\frac{A_{N, t}}{\bar{A}_{N}}\right)=\rho_{a}^{N} \log \left(\frac{A_{N, t-1}}{\bar{A}_{N}}\right)+\varepsilon_{t}^{N}, \quad \varepsilon_{t}^{N} \sim N\left(0, \sigma_{a}^{N}\right)$

Terms of trade shock, exports: $\quad \log \left(\frac{S_{t}}{\bar{S}}\right)=\rho_{s} \log \left(\frac{S_{t-1}}{\bar{S}}\right)+\varepsilon_{t}{ }^{\sigma}, \quad \varepsilon_{t}^{\sigma} \sim N\left(0, \sigma_{s}\right)$

Foreign interest rate shock: $\quad \log \left(\frac{R_{t}^{*}}{\bar{R}^{*}}\right)=\rho_{r} \log \left(\frac{R_{t-1}^{*}}{\bar{R}^{*}}\right)+\varepsilon_{t}^{r}, \quad \varepsilon_{t}^{r} \sim N\left(0, \sigma_{r}\right)$

In the baseline model, we focus on productivity shocks in the tradable goods sector as that is central to the questions posed in this paper and is a common phenomenon among emerging markets relative to their trading partners.

\subsection{Policy evaluation}

Given our objective of determining the distributional effects of different monetary policy rules, we need suitable metrics to evaluate both the short-term and long-term effects of specific policy choices in response to particular sources of shocks.

To evaluate short-term effects, we rely on impulse response functions and use consumption as a direct measure of welfare. For instance, given a one standard deviation positive productivity shock in the tradable goods sector, we calculate the accumulated consumption 
gains or losses for a specific type of household for a sufficiently long period of time $\mathrm{T}$ when the central bank uses an alternative policy rule (relative to the baseline policy rule). In other words, the cumulative difference between the two impulse responses represents the short-term effects of different monetary policy rules on households' consumption.

To measure long-run effects, we compare welfare levels of a representative household in a given sector under alternative policy rules relative to the baseline rule. The long-run effects of alternative monetary policy rules can be quite different from their short-run effects because the former involve an evaluation of unconditional welfare in an economy facing continuous symmetric productivity shocks.

We compute the second-order accurate consumer welfare measure under different monetary policy regimes as in Schmitt-Grohé and Uribe (2004, 2007). Welfare of households in the tradable goods sector is denoted by $V_{t}^{T}$ and that of households in the nontradable goods sector is denoted by $V_{t}^{N}$. Aggregate welfare in the economy is defined as the populationweighted sum of the welfare of the two types of households: $V_{\text {total }}=\lambda V_{t}^{T}+(1-\lambda) V_{t}^{N}$. We define $\omega$, the welfare gain from adopting an alternative policy rule, as the fraction that has to be added to the inflation targeting regime's (denoted by $r$ ) consumption process to yield a level of aggregate welfare equivalent to that under regime $a$. That is,

$$
V_{0}^{a}=E_{0} \sum_{t=0}^{\infty} \beta^{t} U\left((1+\omega) C_{t}^{r}, N_{t}^{r}\right)
$$

A positive value of $\omega$ means that welfare is higher under the alternative policy rule. The welfare gain $\omega$ is given by

$$
\omega=\left[\frac{V_{0}^{a}+D_{0}^{r}}{V_{0}^{r}+D_{0}^{r}}\right]^{\frac{1}{1-\sigma}}-1
$$

where $D_{0}^{r}=E_{0} \sum_{t=0}^{\infty} \beta^{t}\left[\phi_{n} \frac{\left(N_{t}^{r}\right)^{1+\psi}}{1+\psi}\right]$. A value of $\omega * 100=1$, represents a gain of one percentage point of permanent consumption under the alternative policy rule relative to the baseline. 


\subsection{Parameter selection}

Parameter selection for the model is a challenging task. There is no consensus on the values of some parameters and those used in the literature are mostly based on micro data from advanced countries. We pick baseline parameters from the existing literature and then do extensive sensitivity analysis with respect to the choice of key parameters. Values of the key model parameters are summarized in Table 1. The time period in our model is equivalent to one quarter and we pick parameters corresponding to this frequency.

We choose $\beta=0.99$, which amounts to an annual real interest rate of 4 percent. We use $\sigma=2$ as the baseline value of the risk aversion parameter, a value commonly used in the literature on emerging market economies (Aguiar and Gopinath, 2007; Devereux, Lane, and Xu, 2006; García-Cicco, Pancrazi, and Uribe, 2010). The share of home-produced tradable goods, denoted by $a$, is set to be 0.7 . This implies that, in the steady state, 70 percent of all tradable goods consumed in the home country are produced domestically. The consumption weight of tradable goods $b$ is set to be 0.6. The value chosen for $a$ is common in the open economy literature (Obstfeld and Rogoff, 2001) and we use the combination of the shares of the agricultural and manufacturing sectors in emerging market economies to approximate $b$. We set the probability that a price in the nontradable goods sector does not adjust in a given period $(\theta)$ at 0.66 (Rotemberg and Woodford, 1997). This implies that prices in that sector remain fixed for a mean duration of 3 quarters, consistent with the micro evidence for both advanced economies and emerging markets. ${ }^{11}$

An important set of parameters in our model concerns the elasticities of substitution across different varieties of nontradable goods, between tradable and nontradable goods, and across different countries. ${ }^{12}$ The elasticities of substitution between home- and foreignproduced tradable goods and across different foreign countries are assumed to be 2 (Obstfeld

\footnotetext{
${ }^{11}$ For evidence on price stickiness in emerging markets, see Gouvea (2007) for Brazil; Medina, Rappoport, and Soto (2007) for Chile; Gagnon (2009) for Mexico; and Creamer and Rankin (2008) for South Africa.

${ }^{12}$ Obstfeld and Rogoff (2005) have a detailed discussion regarding parameter selection in such models and review relevant empirical studies.
} 
and Rogoff, 2005, 2007). The elasticity of substitution between tradable and nontradable goods is set at 0.6 based on the existing literature (Mendoza, 1995; Lane and Milesi-Ferretti, 2004). The elasticity of substitution across different varieties of nontradable goods, $\varepsilon$, is set to 11, implying a steady state mark-up of 1.1 (Clarida, Galí, and Gertler, 1999, 2002).

For our benchmark case, the Frisch elasticity $(1 / \psi)$ is assumed to be $2 / 3$ (in other words, $\psi=1.5) .{ }^{13}$ For the monetary policy parameters, we follow Clarida, Galí, and Gertler (1998) and choose $\rho=0.75$ and $\phi_{\pi}=1.5$. We set the values of the AR (1) coefficients at 0.9 for productivity shocks to both the tradable and nontradable goods sectors, consistent with the literature (e.g., Aguiar and Gopinath, 2007). The volatility of productivity shocks in emerging market economies is higher than in advanced countries (García-Cicco, Pancrazi, and Uribe, 2010). We set the standard deviation of the tradable goods sector productivity shock at $\sigma_{a}^{H}=0.02$ and the standard deviation of the nonfood productivity shock at $\sigma_{a}^{N}=$ 0.015. We follow Devereux, Lane, and Xu (2006) in calibrating the persistence and standard deviation of the foreign interest rate shock and choose $\rho_{r}=0.46$ and the standard deviation parameter $\sigma_{r}=0.012$. For terms of trade shocks, we follow Mendoza (1995) and choose $\rho_{s}=0.47$ and $\sigma_{s}=0.047$.

\section{Baseline Results}

We now present the main results of the model and evaluate the short-run and long-run consequences, both at the aggregate level and across different types of households, of adopting different monetary policy rules. The baseline policy rule for the central bank is inflation targeting. ${ }^{14}$ Two alternative policy rules are also considered. First, nominal exchange rate smoothing, which is akin to the "leaning against the wind" approach ostensibly adopted by

\footnotetext{
${ }^{13}$ Estimates of this parameter range from 0.25 to 1 . Given the gap between macro- and micro-level estimates of labor supply elasticity and the informal nature of labor markets in developing countries, we set the baseline labor supply elasticity to be slightly higher than the common value used for developed countries.

${ }^{14}$ The version of inflation targeting that we consider is in effect "strict" headline inflation targeting as it does not include other variables such as the output gap and wage inflation in the central bank's policy rule. We consider flexible inflation targeting later in the paper.
} 
many emerging market central banks. Second, a fixed nominal exchange rate.

\subsection{Short-run effects}

To understand the dynamics of key variables in the model, we begin by analyzing their responses to a positive productivity shock in the home economy's tradable goods sector. This shock is to be interpreted as a country-specific productivity shock that is transitory but persistent and, in most models including this one, induces a real exchange rate appreciation. Given the lack of a well-defined welfare criterion when we focus on just the short run, our approach is to evaluate the effects of different policy rules on the consumption patterns of the two types of households in response to the productivity shock.

Figure 1 shows the impulse responses for key variables under different monetary policy rules. A positive productivity shock of course improves aggregate consumption, so the distributional consequences are of more interest. The consumption of households in the tradable goods sector is higher by 0.4 percent (over a 16-quarter horizon) when the central bank dampens exchange rate appreciation in the short run relative to the case where the central bank adopts inflation targeting. By contrast, the consumption of nontradable goods households is higher under inflation targeting compared to any degree of exchange rate management. These distributional effects are monotonic in the weight ascribed to the nominal exchange rate in the central bank's policy rule, with the effects being largest in the case of a fixed exchange rate. As expected, the real exchange rate eventually adjusts through higher inflation and there is no difference in the long-run path of the real exchange rate independent of the policy rule.

Why do households in the tradable goods sector do better under a policy rule that involves nominal exchange management rather than inflation targeting? These households do not enjoy the benefits of higher productivity in the tradable goods sector as much as households in the nontradable goods sector because the shock leads to a sharp increase in the relative price of nontradable goods. A temporary increase in the productivity of tradable 
goods production drives up the relative price of nontradable goods through two channels: an increase in the price of nontradable goods and a decrease in the price of tradable goods. Since the price of tradable goods is determined in international markets and priced in the foreign currency, the nominal exchange rate directly pins down its price in domestic currency.

When the monetary policy rule involves pure inflation targeting, the home currency appreciates following the positive productivity shock, leading to a drop in the price of tradable goods. As a result, the relative price of nontradable goods tends to rise even more. By contrast, if the central bank offsets or dampens nominal exchange rate appreciation, tradable goods prices do not adjust as much and the burden of relative price adjustment falls to the nontradable goods sector. Price stickiness in that sector implies that the increase in nontradable goods' prices is more gradual, so the relative price of nontradable goods adjusts more slowly. Thus, households in the tradable goods sector enjoy a relatively more favorable relative price and achieve higher consumption levels in the short run, compared to the scenario of an inflation targeting central bank. In fact, the more the central bank manages the nominal exchange rate, the smoother the relative price will be and the higher the consumption gain of households in the tradable goods sector relative to the inflation targeting case. $^{15}$

This process, despite its similarity to the traditional Balassa-Samuelson effect, differs in the underlying mechanism. In the Balassa-Samuelson framework, higher productivity growth in the tradable goods sector pushes up wages in that sector and, in order to equalize wages across sectors, the relative price of nontradable goods must rise. In our model, a temporary increase in productivity in the tradable goods sector drives up the relative price of nontradable goods not through wage equalization, since labor is assumed to be immobile, but through households' consumption demand for tradable and nontradable goods.

\footnotetext{
${ }^{15}$ Since the tradable goods sector has flexible prices, employment and wage responses in that sector are similar across different policy rules when the sector experiences a productivity shock.
} 


\subsection{Long-run effects}

Next, we turn to an evaluation of the long-run effects of different policy rules using the welfare criterion defined in Section 2.6. Table 2 shows the implications under different policy rules for both short-run consumption paths and long-run welfare. While targeting the nominal exchange rate provides short-term benefits to households working in the tradable goods sector relative to those working in the nontradable goods sector, the long-run welfare effects are, surprisingly, reversed. In the long run, households working in the tradable goods sector do worse under either of the policies that involve exchange rate management. Under a fixed exchange rate, the welfare of households in the traded goods sector is lower by 0.12 percent of lifetime consumption relative to a pure inflation targeting regime. By contrast, households working in the nontradable goods sector do marginally better in the long run when the central bank does not follow pure inflation targeting. More interestingly, aggregate welfare of households in the economy is also slightly lower when the central bank manages the nominal exchange rate. When the central bank's policy rule involves a fixed exchange rate rather than exchange rate smoothing, these results all go in the same direction and are stronger.

A key point to keep in mind is that the short-run effects on consumption are based on a scenario where there is a transitory positive shock to productivity in the tradable goods sector. So our statements about consumption paths in the short run are conditional on that specific shock. When conducting welfare evaluations in the long run, we of course need to consider random productivity shocks, both positive and negative. In this case, a monetary policy rule that attempts to stabilize the nominal exchange rate magnifies the volatility of consumption of households in the tradable goods sector but reduces consumption volatility for households in the nontradable goods sector. Since long-run welfare levels in our model depend crucially on the volatility of consumption, households working in the tradable goods sector paradoxically attain a lower level of welfare if monetary policy deviates from pure 
inflation targeting.

In short, a policy of stabilizing the exchange rate in order to benefit households in the tradable goods sector in the short run can, in the long run, generate unfavorable consequences for those very households and for the economy as a whole.

\subsection{Sensitivity analysis}

As noted earlier, it is difficult to pin down the values of certain parameters in our model due to the dearth of relevant empirical evidence for emerging market economies. We now report sensitivity tests to evaluate the impact of a few key parameters on both short-run and longrun distributional effects. This exercise also provides further insights into the mechanisms underlying our key results.

The distributional effects are most significant when the elasticity of substitution between tradable and nontradable goods is smaller, the share of tradable goods sector output is not large, and the Frisch elasticity of labor supply is high. Our key conclusions concerning the distributional consequences of alternative monetary policy rules are preserved across a broad range of values for these key parameters.

\subsubsection{Elasticity of substitution between tradable and nontradable goods}

The elasticity of substitution between tradable and nontradable goods $(\xi)$ determines how responsive the relative price of nontradable goods is to productivity shocks in the tradable goods sector. When the elasticity of substitution is low, a temporary increase (decrease) in the supply of tradable goods when that sector experiences a positive productivity shock is likely to drive up (down) the relative price of nontradable goods to a greater extent. As a result, the distributional effects of monetary policy are also likely to be larger.

As shown in Table 3 (Panel A), the sizes of both short-run and long-run effects of nominal exchange rate management depend on this elasticity of substitution. When the elasticity is lower, the short-run consumption gains of households working in the tradable goods sector 
and short-run consumption losses of households working in the nontradable goods sectors both increase. Similarly, the absolute values of long-run welfare effects are also larger when the elasticity is lower. The short-run aggregate effects do not change much with variations in this parameter, but the long-run negative welfare effects of exchange rate management relative to inflation targeting tend to be larger the lower is this elasticity.

\subsubsection{Share of tradable goods sector output}

The share of tradable goods sector output $(b)$ affects the relative share of tradable goods in the final consumption bundle and, consequently, influences relative price fluctuations. As shown in Table 3 (Panel B), both the short-run consumption gains and the long-run welfare losses from the central bank's exchange rate management are smaller (in absolute terms) for households working in the tradable goods sector when the share of tradable goods sector output is higher. The reason is that as the tradable goods sector accounts for a larger share, the home economy converges to a flexible price economy in which monetary policy does not have real effects. By contrast, as the relative size of the tradable goods sector falls, the shortrun consumption gains and long-run welfare losses for households working in this sector both become larger. Aggregate short-run consumption gains and long-run welfare losses behave similarly.

When the relative size of the tradable goods sector increases, aggregate inflation is more sensitive to exchange rate policy because tradable goods prices are determined by the nominal exchange rate. This increases the impact of nominal exchange rate management on households working in the nontradable goods sector. The model confirms this intuition as the short-run consumption losses and long-run welfare gains of households working in the nontradable goods sector increase when $b$ is larger. 


\subsubsection{Frisch elasticity of labor supply}

The Frisch elasticity is the elasticity of labor supply conditional on a fixed level of consumption. In the model, it is given by the inverse of the parameter $\phi$. In Table 3 (Panel C), we compare the short-run consumption and long-run welfare levels under different values of $\psi$. The results are intuitive. The sizes of the short-run and long-run effects are larger when the Frisch elasticity of labor supply is higher (corresponding to a smaller $\psi$ ).

When the Frisch elasticity of labor supply is higher, households' labor supply is more responsive to changes in real wages. Consequently, when the central bank manages the nominal exchange rate, the real wage for households working in the tradable goods sector is higher for a given positive productivity shock, so the gain in consumption is also higher as the labor supply response is stronger. For the same reason, the consumption loss for households working in the nontradable goods sector is higher.

\section{Extensions}

In this section, we discuss a few extensions to the model that enable us to study a broader range of policy questions. First, targeting the real exchange rate leads to almost identical short-run and long-run effects as targeting the nominal exchange rate. Second, we find that the distributional effects of nominal exchange rate management are larger when the economy is subject to controls on cross-border capital flows. We also find that a fixed exchange rate delivers worse outcomes relative to inflation targeting even in the short run-both for households in the tradable goods sector and the aggregate economy-when the economy faces positive shocks to productivity in the nontradable goods sector or to foreign interest rates. It is important to emphasize here that we cannot compare consumption and welfare gains or losses across different versions of the basic model since they have different steady states. Our comparisons are about the effects of different monetary policy rules conditional on a particular model setting. 


\subsection{Real exchange rate management}

Calvo, Reinhart, and Vegh (1995) document that emerging market central banks often try to target the real exchange rate, even though such targeting is only effective temporarily and could even generate aggregate instability (Uribe, 2003). Nevertheless, in the short run, real exchange rate changes do tend to be closely correlated with the nominal exchange rate changes (see, e.g., Burstein and Gopinath, 2014). To evaluate the implications of real exchange rate targeting, we modify the baseline interest rate rule in equation (12) to include the change in the real exchange rate rather than the nominal exchange rate:

$$
\log \left(\frac{R_{t}}{\bar{R}}\right)=\rho \log \left(\frac{R_{t-1}}{\bar{R}}\right)+(1-\rho)\left[\phi_{\pi} \log \left(\frac{\pi_{t}}{\bar{\pi}}\right)+\phi_{e} \log \left(\frac{q_{t}^{e}}{q_{t-1}^{e}}\right)\right]
$$

where $q_{t}^{e}$ is the real exchange rate.

In Table 4 (Panel A), we compare the short-run and long-run effects of targeting the nominal and real exchange rates, with inflation targeting being the benchmark rule. There is little difference between the two exchange rate targets. In the short run, prices are sticky, so the two exchange rates are correlated and the corresponding interest rate rules suggest similar policy rates. In technical terms, because $\log \left(q_{t}^{e} / q_{t-1}^{e}\right)=\log \left(e_{t} / e_{t-1}\right)-\pi_{t}$, the only difference between targeting the real and nominal exchange rates is the implied response of inflation. In the long run, prices become flexible, so there is no difference in welfare outcomes between the two targeting rules.

\subsection{Capital controls}

Emerging market economies often supplement monetary policy with capital controls to reduce capital flow and currency volatility, and also to make it easier to manage the exchange rate. These controls can take the form of bureaucratic restrictions on international capital flows (Chang, Liu, and Spiegel, 2015), a tax on international financial transactions (Jeanne and Korinek, 2010; Gabaix and Maggiori, 2015), or simply a wedge in the uncovered interest 
parity equation (Farhi and Werning, 2014).

We introduce capital controls in a manner similar to Chang, Liu, and Spiegel (2015) by setting the parameter $\psi_{B}$, which represents the one-period portfolio holdings cost for foreign bond holdings, to be 1 for the case with capital controls. This is a plausible value for this parameter based on the estimates of García-Cicco, Pancrazi, and Uribe (2010). Under the capital controls scenario, households working in the tradable goods sector face a higher cost in smoothing consumption intertemporally using foreign bonds. This renders the relative price between tradable and nontradable goods more responsive to productivity shocks as well as alternative monetary policy rules. ${ }^{16}$

Figure 2 shows that household consumption levels are more responsive to productivity shocks than in the baseline model. Moreover, monetary policy has larger distributional effects compared to the baseline model. When faced with capital controls, households working in the tradable goods sector spend more of their income when a positive productivity shock hits their sector, resulting in an even larger increase in the relative price of nontradable goods. Managing the nominal exchange rate has larger distributional effects in the short run, following the same mechanism discussed in the baseline model but with larger magnitudes. Thus, in an environment with capital controls, emerging market central banks are more likely to use exchange rate management if they are subject to political pressures from households in the tradable goods sector as the effects of such policies are greater relative to inflation targeting.

Table 4 (Panel B) shows the short-run and long-run distributional effects of alternative monetary policy rules in an economy with capital controls. Relative to the baseline model with unrestricted capital flows (Table 2), the distributional effects are stronger under capital controls. Notably, not only are these effects stronger for both types of households, the aggregate effects are also larger. In other words, while policymakers have a stronger incentive

\footnotetext{
${ }^{16}$ Jeanne and Korinek (2010) and Jeanne (2012) show that capital controls can be used to affect the real exchange rate in a model that has tradable and nontradable goods, although their models are entirely real-there is no money or monetary policy.
} 
to use monetary policy to achieve distributional objectives in the short run, this comes at a higher cost in terms of aggregate welfare in the long run.

\subsection{Fiscal policy}

As discussed in the baseline model, developing countries' central banks can use monetary policy to achieve certain distributional consequences. By targeting the nominal exchange rate, the central bank can smooth the adjustment of the relative price of nontradable goods and increase the consumption of households working in the tradable goods sector in the short run. However, monetary or exchange rate policies are not necessarily the right tools to deal with domestic or external shocks in an open economy setting.

Instead, fiscal policy is often the more efficient and direct policy instrument for redistribution across households. ${ }^{17}$ The tax and transfer system in emerging market countries is typically not sophisticated enough to allow for state-contingent direct transfers that can help complete financial markets and achieve perfect risk-sharing. Nevertheless, there are simple fiscal tools that are feasible to implement and could attain some of these benefits. In particular, we study the impact of a proportional tax and subsidy on nontradable goods and compare their short-run and long-run effects with the effects of nominal exchange rate targeting. Our interest here is in analyzing how fiscal and monetary policies interact in a small open economy setting with financial frictions in determining distributional effects of various shocks. This allows us to make a normative statement about whether fiscal policy would be a more effective tool than monetary policy even if the government's focus is on achieving specific distributional objectives.

To be more specific, we consider alternative fiscal policy regimes with different tax rates

\footnotetext{
${ }^{17}$ Farhi, Gopinath, and Itskhoki (2014) show that a small set of conventional fiscal instruments can robustly replicate the real allocations attained under a nominal exchange rate devaluation in a dynamic New Keynesian open economy environment. However, theirs is a one-sector model without financial frictions or heterogeneous households. Schmitt-Grohé and Uribe (2011) show that, in a model with downward wage rigidity and inelastic labor supply, a payroll tax subsidy can replicate the effects of a nominal devaluation. Correia, Nicolini, and Teles (2008) and Correia et al. (2013) show that fiscal instruments can replicate the effects of optimal monetary policy. This section of our paper is related to these papers, but none of them deals with distributional issues.
} 
on nontradable goods: the baseline case with no taxes; a 3 percent tax on nontradable goods, with the proceeds of the tax distributed in a lump sum fashion across all households in the economy; and a 3 percent subsidy on nontradable goods, with the subsidy financed through a lump sum tax on all households. The tax/subsidy is set as a wedge between labor wages and goods prices. Furthermore, to facilitate comparison between policy regimes, there is a direct transfer between households to keep their respective steady-state consumption levels unchanged from the baseline case. Thus, the shift in relative prices is the main channel through which fiscal policy has short-run effects. Regardless of the fiscal policy setting, the monetary policy rule is pure inflation targeting.

The results are summarized in Table 4 (Panel C). A tax on nontradable goods has distributional effects that are similar to nominal exchange rate targeting. The imposition of taxes on nontradable goods implies that households working in the tradable goods sector will be better off after a positive productivity shock to that sector on account of the relative price effect. By contrast, households working in the nontradable goods sector have lower short-run consumption under this regime. The results are reversed but symmetric when there is a subsidy on nontradable goods. While the short-run effects are similar to a policy of targeting the nominal exchange rate, the long-run welfare effects are different. In fact, fiscal policy is close to welfare neutral, both at the household and aggregate levels because the constant sales tax (or subsidy) on nontradable goods does not affect households' intertemporal choices.

The implication is that fiscal policy can in principle be more effective than exchange rate policy for attaining distributional objectives. While previous authors have made the point that fiscal policy can do better than exchange rate policy (or can serve as a substitute when there are constraints on exchange rate management) in an open economy setting, our contribution here is to show that this is true even when the objectives are related to distributional rather than aggregate consequences. 


\subsection{Flexible inflation targeting}

In practice, emerging market central banks set interest rates to manage not just inflation and the exchange rate but also the output gap (the deviation of output from its steady state or trend level). In a specific setting that incorporates local currency pricing, Engel (2011) finds that the optimal instrument rule involves responding only to the deviation of inflation from its target level even if the central bank cares about inflation, output, and exchange rate misalignment. Nevertheless, it is relevant in a more general setting to consider flexible inflation targeting as the baseline for assessing the distributional effects of nominal exchange rate management. This is consistent with the basic formulation of the Taylor (1993) rule for monetary policy.

To this end, we modify the interest rate rule in equation (12) to include a positive weight on the output gap. This yields the following operational rule for monetary policy:

$$
\log \left(\frac{R_{t}}{\bar{R}}\right)=\rho \log \left(\frac{R_{t-1}}{\bar{R}}\right)+(1-\rho)\left[\phi_{\pi} \log \left(\frac{\pi_{t}}{\bar{\pi}}\right)+\phi_{y} \log \left(\frac{Y_{t}}{\bar{Y}}\right)+\phi_{e} \log \left(\frac{e_{t}}{e_{t-1}}\right)\right]
$$

where $\phi_{y}$ is the output gap response coefficient, $Y_{t}$ represents output in period $t$, and $\bar{Y}$ denotes steady-state output. Since a period in our model is equal to one quarter, we set $\phi_{y}$ to 0.125 as the baseline value. As discussed in Galí (2015) and Smets and Wouters (2007), this matches the annualized coefficient value proposed in Taylor (1993).

We summarize the results from this more general formulation of monetary policy rules in Table 4 (Panel D). The baseline is flexible inflation targeting and the output gap term also enters the exchange rate smoothing rule but does not appear in the fixed exchange rate rule. The short-run distributional effects of exchange rate targeting rules relative to the baseline are larger when the central bank responds to the output gap. The reason is that a positive productivity shock now leads to a positive output gap, which drives up the interest rate and, consequently, the nominal exchange rate as well. Hence, exchange rate management 
now involves large short-run consumption gains for households in the tradable goods sector relative to the baseline rule. Households in the nontradable goods sector, by contrast, do significantly worse in the short run relative to the baseline rule because the adjustment of relative prices between tradable and nontradable goods is less favorable to them.

As expected, the long-run welfare effects are similar to the baseline experiments with strict inflation targeting, with the welfare of households in the tradable goods sector and aggregate welfare both lower when the central bank incorporates the exchange rate in its operational rule. The long-run welfare effects again mostly reflect the consumption volatility channel as nominal rigidities play no role in the long run.

\subsection{Alternative shocks}

When the central bank uses monetary policy to achieve certain distributional objectives, it commits to a particular policy rule. However, this may have unexpected consequences when the economy is hit by shocks other than the productivity shocks to the tradable goods sector that we have emphasized up to this point. We now examine the short-run and long-run effects of nominal exchange rate management when the economy faces three other types of shocks. ${ }^{18}$ The results discussed below are summarized in Table 5.

\subsubsection{Productivity shocks in the nontradable goods sector}

We first consider a scenario in which the economy only faces productivity shocks in the nontradable goods sector (see first two rows of Table 5). In this case, relative to inflation targeting, nominal exchange rate management has adverse consequences for households in the tradable goods sector both in the short run and the long run. A positive productivity shock in the nontradable goods sector drives down the relative price of nontradable goods, leading to higher consumption for households in the tradable goods sector. Following the

\footnotetext{
${ }^{18}$ In this section, we separately study the short-run and long-run effects when the economy faces only one specific type of shocks at a time. This decomposition of the effects of different types of shocks is valid given the theoretical result in Schmitt-Grohé and Uribe (2004).
} 
same mechanism as in the baseline model, nominal exchange rate management slows down the adjustment in the relative price compared to a policy of inflation targeting, thus hurting households working in the tradable goods sector and benefiting those working in the nontradable goods sector. Under a fixed exchange rate, households in the traded goods sector face a consumption loss of 0.34 percent (over 16 quarters) relative to pure inflation targeting; over the long run, their welfare loss amounts to 0.16 percent of lifetime consumption.

\subsubsection{Terms of trade shocks}

Terms of trade fluctuations are important in driving fluctuations in emerging market economies (see, e.g., Mendoza, 1995). In the second panel of Table 5 (third and fourth rows), we examine the distributional effects of monetary policy when the home economy faces terms of trade shocks. A higher terms of trade implies a higher price of home-produced tradable goods in the foreign currency. Hence, targeting the nominal exchange rate implies a higher relative price of tradable goods than is the case with inflation targeting. This benefits households working in the tradable goods sector in the short run. However, the long-run welfare consequences of the particular choice of policy rule are minimal when the economy is exposed to these shocks because import and export prices are perfectly flexible.

\subsubsection{Foreign interest rate shocks}

Emerging market economies are exposed to foreign interest rate shocks that have significant effects on their business cycles and exchange rate fluctuations. ${ }^{19}$ When dealing with such shocks, we find that a fixed exchange rate benefits households working in the nontradable goods sector but hurts households working in the tradable goods sector both in the short and long run (see Table 5, last two rows).

A temporary increase in the foreign interest rate tends to cause the domestic currency to depreciate and drive up the demand for home-produced tradable goods. In this case,

\footnotetext{
${ }^{19}$ For some early work see, for example, Neumeyer and Perri (2005) and Aguiar and Gopinath (2006).
} 
stabilizing the nominal exchange rate implies a higher domestic interest rate and encourages households to save more. Households working in the nontradable goods sector are better off in the short run compared to the outcome under an inflation targeting regime because of a smaller increase in the relative price of tradable goods. By contrast, households working in the tradable goods sector are not as well off. The long-run welfare effects for both types of households have the same signs as in the short run (better for households in the nontradable goods sector, worse for those in the tradable goods sector) because targeting the nominal exchange rate leads to more volatile nominal interest rates. Since only households working in the tradable goods sector have access to financial markets, they are exposed to interest rate volatility, rendering their consumption more volatile. ${ }^{20}$

\section{Concluding Remarks}

In this paper, we developed a two sector, heterogeneous agent model with incomplete financial markets that allowed us to jointly examine the distributional effects as well as aggregate welfare implications of alternative monetary policy rules. The features that we incorporated in the model-incomplete financial markets, sticky prices in the nontradable goods sector, limited labor mobility across sectors-make it especially relevant for the analysis of monetary policy in emerging market economies.

Our main result is that, relative to pure inflation targeting, exchange rate management has a positive effect on the short-run consumption of households in the tradable goods sector when that sector faces productivity shocks. Indeed, political pressure from the tradable goods sector, fearful of a loss of external competitiveness due to exchange rate appreciation, is often a key reason why emerging market central banks try to manage the nominal exchange rate. However, we find that such a policy can actually reduce the welfare of households in the tradable goods sector in the long run as it increases their consumption volatility. Moreover,

\footnotetext{
${ }^{20}$ Some authors have argued that emerging market economies face highly persistent foreign interest rate shocks (see, e.g., García-Cicco, Pancrazi, and Uribe, 2010; Chang, Liu, and Spiegel, 2015). Allowing for more persistent foreign interest rate shocks magnifies the effects discussed in this sub-section.
} 
such a policy can have negative aggregate welfare consequences even in the short run.

The model could be extended to better capture the complex policy choices that emerging market central bankers face (Prasad, 2014). For instance, incorporating physical capital in the model would provide an alternative channel for intertemporal consumption smoothing but would at the same time sharpen the policy dilemmas as interest rate changes intended to keep the exchange rate stable could magnify domestic macroeconomic fluctuations. Another extension would be to allow for the common practice of sterilized intervention in foreign exchange markets in order to evaluate the distributional effects of alternative strategies for exchange rate management. We leave such extensions to future work. 


\section{References}

Aguiar, Mark and Gita Gopinath. 2006. "Emerging market fluctuations: The role of interest rates and productivity shocks." In Tenth Annual Conference on the Central Bank of Chile, "Current Account and External Financing".

- 2007. "Emerging market business cycles: The cycle is the trend." Journal of Political Economy 115 (1):69-102.

Anand, Rahul, Eswar S. Prasad, and Boyang Zhang. 2015. "What measure of inflation should a developing country central bank target?" Journal of Monetary Economics 74:102-116.

Artuç, Erhan, Daniel Lederman, and Guido G Porto. 2013. "A mapping of labor mobility costs in developing countries." World Bank Policy Research Working Paper No. 6556.

Bell, Venetia, Michael Joyce, Zhuoshi Liu, and Chris Young. 2012. "The distributional effects of asset purchases." Bank of England Quarterly Bulletin Q3.

Benigno, Gianluca and Pierpaolo Benigno. 2003. "Price stability in open economies." Review of Economic Studies 70 (4):743-764.

Benigno, Pierpaolo. 2004. "Optimal monetary policy in a currency area." Journal of International Economics 63 (2):293-320.

Brunnermeier, Markus K. and Yuliy Sannikov. 2012. "Redistributive monetary policy." In Proceedings of the 2012 Jackson Hole Symposium. Federal Reserve Bank of Kansas City Kansas City, KS, 331-384.

Burstein, Ariel and Gita Gopinath. 2014. "International prices and exchange rates." In Handbook of International Economics, vol. 4, edited by Gita Gopinath, Elhanan Helpman, and Kenneth Rogoff.

Calvo, Guillermo A. 1983. "Staggered prices in a utility-maximizing framework." Journal of Monetary Economics 12 (3):383-398.

Calvo, Guillermo A., Carmen M. Reinhart, and Carlos A. Vegh. 1995. "Targeting the real exchange rate: Theory and evidence." Journal of Development Economics 47 (1):97-133.

Chang, Chun, Zheng Liu, and Mark M. Spiegel. 2015. "Capital controls and optimal Chinese monetary policy." Journal of Monetary Economics 74:1-15.

Clarida, Richard, Jordi Galí, and Mark Gertler. 1998. "Monetary policy rules in practice: Some international evidence." European Economic Review 42 (6):1033-1067.

. 1999. "The science of monetary policy: A new Keynesian perspective." Journal of Economic Literature 37 (4):1661-1707.

- 2002. "A simple framework for international monetary policy analysis." Journal of Monetary Economics 49 (5):879-904. 
Coibion, Olivier, Yuriy Gorodnichenko, Lorenz Kueng, and John Silvia. 2012. "Innocent bystanders? Monetary policy and inequality in the US." NBER Working Paper No. 18170.

Correia, Isabel, Emmanuel Farhi, Juan Pablo Nicolini, and Pedro Teles. 2013. "Unconventional fiscal policy at the zero bound." American Economic Review 103 (4):1172-1211.

Correia, Isabel, Juan Pablo Nicolini, and Pedro Teles. 2008. "Optimal fiscal and monetary policy: Equivalence results." Journal of Political Economy 116 (1):141-170.

Corsetti, Giancarlo and Paolo Pesenti. 2005. "International dimensions of optimal monetary policy." Journal of Monetary Economics 52 (2):281-305.

Creamer, Kenneth and Neil A. Rankin. 2008. "Price setting in South Africa 2001-2007: Stylised facts using consumer price micro data." Manuscript, University of the Witwaterstrand.

Demirgüç-Kunt, Asli and Leora F. Klapper. 2012. "Measuring financial inclusion: The global findex database." World Bank Policy Research Working Paper No. 6025.

Devereux, Michael B. and Charles Engel. 2003. "Monetary policy in the open economy revisited: Price setting and exchange-rate flexibility." Review of Economic Studies 70 (4):765783.

Devereux, Michael B., Philip R. Lane, and Juanyi Xu. 2006. "Exchange rates and monetary policy in emerging market economies." Economic Journal 116 (511):478-506.

Doepke, Matthias and Martin Schneider. 2006. "Inflation and the redistribution of nominal wealth." Journal of Political Economy 114 (6):1069-1097.

Doepke, Matthias, Martin Schneider, and Veronika Selezneva. 2015. "Distributional effects of monetary policy." Hutchins Center Working Paper No. 14.

Engel, Charles. 2011. "Currency misalignments and optimal monetary policy: A reexamination." American Economic Review 101 (6):2796-2822.

Erosa, Andrés and Gustavo Ventura. 2002. "On inflation as a regressive consumption tax." Journal of Monetary Economics 49 (4):761-795.

Farhi, Emmanuel, Gita Gopinath, and Oleg Itskhoki. 2014. "Fiscal devaluations." Review of Economic Studies 81 (2):725-760.

Farhi, Emmanuel and Ivan Werning. 2014. "Dilemma not trilemma? Capital controls and exchange rates with volatile capital flows." IMF Economic Review 62 (4):569-605.

Frömmel, Michael, Garo Garabedian, and Franziska Schobert. 2011. "Monetary policy rules in Central and Eastern European countries: Does the exchange rate matter?" Journal of Macroeconomics 33 (4):807-818. 
Gabaix, Xavier and Matteo Maggiori. 2015. "International liquidity and exchange rate dynamics." Quarterly Journal of Economics 13 (3):1369-1420.

Gagnon, Etienne. 2009. "Price setting during low and high inflation: Evidence from Mexico." Quarterly Journal of Economics 124 (3):1221-1263.

Galí, Jordi. 2015. Monetary Policy, Inflation, and the Business Cycle: An Introduction to the New Keynesian Framework and Its Applications. Princeton University Press, 2 ed.

Galí, Jordi, J David López-Salido, and Javier Vallés. 2004. "Rule-of-thumb consumers and the design of interest rate rules." Journal of Money, Credit and Banking 36 (4):739-763.

Galí, Jordi and Tommaso Monacelli. 2005. "Monetary policy and exchange rate volatility in a small open economy." Review of Economic Studies 72 (3):707-734.

- 2008. "Optimal monetary and fiscal policy in a currency union." Journal of International Economics 76 (1):116-132.

García-Cicco, Javier, Roberto Pancrazi, and Martín Uribe. 2010. "Real business cycles in emerging countries?" American Economic Review 100 (5):2510-31.

Gornemann, Nils, Keith Kuester, and Makoto Nakajima. 2014. "Doves for the rich, hawks for the poor? Distributional consequences of monetary policy." Working paper, Federal Reserve Bank of Philadelphia.

Gouvea, Solange. 2007. "Price rigidity in Brazil: Evidence from CPI micro data." Banco Central de Brasil Working Paper No. 143.

Jeanne, Olivier. 2012. "Capital account policies and the real exchange rate." NBER Working Paper No. 18404.

Jeanne, Olivier and Anton Korinek. 2010. "Managing credit booms and busts: A Pigouvian taxation approach." NBER Working Paper No. 16377.

Kollmann, Robert. 2002. "Monetary policy rules in the open economy: Effects on welfare and business cycles." Journal of Monetary Economics 49 (5):989-1015.

Korinek, Anton and Jonathan Kreamer. 2014. "The redistributive effects of financial deregulation." Journal of Monetary Economics 68:S55-S67.

Krusell, Per and Anthony A. Smith, Jr. 1998. "Income and wealth heterogeneity in the macroeconomy." Journal of Political Economy 106 (5):867-896.

Lane, Philip R. and Gian Maria Milesi-Ferretti. 2004. "The transfer problem revisited: Net foreign assets and real exchange rates." Review of Economics and Statistics 86 (4):841-857.

Lee, Donghoon and Kenneth I. Wolpin. 2006. "Intersectoral labor mobility and the growth of the service sector." Econometrica 74 (1):1-46. 
Leitemo, Kai and Ulf Söderström. 2005. "Simple monetary policy rules and exchange rate uncertainty." Journal of International Money and Finance 24 (3):481-507.

Liu, Zheng and Mark M. Spiegel. 2015. "Optimal monetary policy and capital account restrictions in a small open economy." IMF Economic Review forthcoming.

Lubik, Thomas A. and Frank Schorfheide. 2007. "Do central banks respond to exchange rate movements? A structural investigation." Journal of Monetary Economics 54 (4):10691087.

McKay, Alisdair and Ricardo Reis. 2015. "The role of automatic stabilizers in the US business cycle." Econometrica forthcoming.

Medina, Juan Pablo, David Rappoport, and Claudio Soto. 2007. "Dynamics of price adjustments: Evidence from micro level data for Chile." Central Bank of Chile Working Paper No. 432.

Meh, Césaire A., José-Víctor Ríos-Rull, and Yaz Terajima. 2010. "Aggregate and welfare effects of redistribution of wealth under inflation and price-level targeting." Journal of Monetary Economics 57 (6):637-652.

Meh, Césaire A. and Yaz Terajima. 2011. "Inflation, nominal portfolios, and wealth redistribution in Canada." Canadian Journal of Economics 44 (4):1369-1402.

Mendoza, Enrique G. 1995. "The terms of trade, the real exchange rate, and economic fluctuations." International Economic Review 36 (1):101-137.

Mohanty, Madhusudan S. and Marc Klau. 2005. "Monetary policy rules in emerging market economies: Issues and evidence." In Monetary Policy and Macroeconomic Stabilization in Latin America, edited by Rolf J. Langhammer and Lúcio Vinhas de Souza. Springer, 205-245.

Neumeyer, Pablo A. and Fabrizio Perri. 2005. "Business cycles in emerging economies: The role of interest rates." Journal of Monetary Economics 52 (2):345-380.

Obstfeld, Maurice and Kenneth S. Rogoff. 2001. "The six major puzzles in international macroeconomics: Is there a common cause?" In NBER Macroeconomics Annual 2000, Volume 15, edited by Ben S. Bernanke and Kenneth Rogoff. MIT press, 339-412.

- 2005. "Global current account imbalances and exchange rate adjustments." Brookings Papers on Economic Activity 2005 (1):67-146.

2007. "The unsustainable US current account position revisited." In Gr Current Account Imbalances: Sustainability and Adjustment. University of Chicago Press, 339-376.

Prasad, Eswar S. 2014. "Distributional effects of macroeconomic policy choices in emerging market economies." IMF Economic Review 62 (3):409-429.

Romer, Christina D. and David H. Romer. 1999. "Monetary policy and the well-being of the poor." Economic Review - Federal Reserve Bank of Kansas City 84 (1):21. 
Rotemberg, Julio J. and Michael Woodford. 1997. "An optimization-based econometric framework for the evaluation of monetary policy." In NBER Macroeconomics Annual 1997, Volume 12, edited by Ben S. Bernanke and Julio J. Rotemberg. MIT Press, 297361.

Schmitt-Grohé, Stephanie and Martín Uribe. 2003. "Closing small open economy models." Journal of International Economics 61 (1):163-185.

—. 2004. "Solving dynamic general equilibrium models using a second-order approximation to the policy function." Journal of Economic Dynamics and Control 28 (4):755-775.

- 2007. "Optimal simple and implementable monetary and fiscal rules." Journal of Monetary Economics 54 (6):1702-1725.

—. 2011. "Pegs and pain." NBER Working Paper No. 16847.

Smets, Frank and Rafael Wouters. 2007. "Shocks and frictions in US business cycles: A Bayesian DSGE approach." American Economic Review 97 (3):586-606.

Sutherland, Alan. 2005. "Incomplete pass-through and the welfare effects of exchange rate variability." Journal of International Economics 65 (2):375-399.

Taylor, John B. 1993. "Discretion versus policy rules in practice." Carnegie-Rochester Conference Series on Public Policy 39:195-214.

Uribe, Martín. 2003. "Real exchange rate targeting and macroeconomic instability." Journal of International Economics 59 (1):137-159. 
Table 1. Parameter Values

\begin{tabular}{|c|c|c|}
\hline Parameter & Definition & Value \\
\hline$\beta$ & Discount factor & 0.99 \\
\hline$\sigma$ & Risk-aversion coefficient & 2 \\
\hline$\lambda$ & Share of households working in the tradable goods sector & 0.6 \\
\hline$a$ & Share of domestically produced tradable goods in total tradable goods & 0.7 \\
\hline$b$ & Share of tradable goods in total output & 0.6 \\
\hline$\varepsilon$ & Elasticity of substitution between different varieties & 11 \\
\hline$\eta$ & Elasticity of substitution between domestic and foreign tradable goods & 2 \\
\hline$\xi$ & Elasticity of substitution between tradable and nontradable goods & 0.6 \\
\hline$\psi$ & Inverse of Frisch elasticity of labor supply & 1.5 \\
\hline$\psi_{b}$ & Interest rate elasticity of debt (for technical reasons only) & 0.0007 \\
\hline$\theta$ & Probability of not being able to reset price in a given quarter & 0.66 \\
\hline \multicolumn{3}{|c|}{$\begin{array}{c}\text { Policy Parameters } \\
\text { (baseline) }\end{array}$} \\
\hline$\rho$ & Degree of interest rate smoothing & 0.75 \\
\hline$\phi_{\pi}$ & Degree of response to inflation & 1.5 \\
\hline$\phi_{y}$ & Degree of response to nominal exchange rate & 0.5 \\
\hline \multicolumn{3}{|c|}{ Shock Parameters } \\
\hline$\rho_{a}^{H}, \sigma_{a}^{H}$ & Productivity shocks in the tradable goods sector: persistence, std. dev. & $0.90,0.020$ \\
\hline$\rho_{a}^{N}, \sigma_{a}^{N}$ & Productivity shocks in the nontradable goods sector: persistence, std. dev. & $0.90,0.015$ \\
\hline$\rho_{s}, \sigma_{s}$ & Terms of trade shocks in the tradable goods sector: persistence, std. dev. & $0.47,0.047$ \\
\hline$\rho_{r}, \sigma_{r}$ & Foreign interest rate shocks: persistence, std. dev. & $0.46,0.012$ \\
\hline
\end{tabular}

Notes: A period in the model corresponds to one quarter. 
Table 2. Short-run and Long-run Effects of Nominal Exchange Rate Management

\begin{tabular}{|c|c|c|c|c|c|c|}
\hline \multirow{2}{*}{ Scenario } & \multicolumn{2}{|c|}{ T Households } & \multicolumn{2}{|c|}{ NT Households } & \multicolumn{2}{|c|}{ Aggregate } \\
\hline & Short-run & Long-run & Short-run & Long-run & Short-run & Long-run \\
\hline Exchange Rate Smoothing & $0.11 \%$ & $-0.03 \%$ & $-0.07 \%$ & $0.01 \%$ & $0.04 \%$ & $-0.01 \%$ \\
\hline Fixed Exchange Rate & $0.39 \%$ & $-0.12 \%$ & $-0.24 \%$ & $0.05 \%$ & $0.14 \%$ & $-0.06 \%$ \\
\hline
\end{tabular}

Notes: This table shows the short-run consumption gains (or losses) and long-run welfare gains from two policy rules-exchange rate smoothing and a fixed exchange rate-relative to a pure inflation targeting rule. The numbers are expressed in percent of cumulative consumption gains/losses over the short run (16 quarters) or percentage points of permanent consumption gains/losses relative to the baseline policy rule in the long run. "T households" refers to households working in the tradable goods sector; "NT households" refers to households working in the nontradable goods sector. 
Table 3. Sensitivity of Results to Key Parameters

\begin{tabular}{|c|c|c|c|c|c|c|c|}
\hline \multirow{2}{*}{ Value } & \multirow{2}{*}{ Scenario } & \multicolumn{2}{|c|}{ T Households } & \multicolumn{2}{|c|}{ NT Households } & \multicolumn{2}{|c|}{ Aggregate } \\
\hline & & Short-run & Long-run & Short-run & Long-run & Short-run & Long-run \\
\hline \multicolumn{8}{|c|}{ A. Elasticity of Substitution between Tradable and Nontradable Goods (baseline: $\xi=0.6$ ) } \\
\hline \multirow{2}{*}{0.5} & Exchange Rate Smoothing & $0.20 \%$ & $-0.06 \%$ & $-0.21 \%$ & $0.05 \%$ & $0.03 \%$ & $-0.02 \%$ \\
\hline & Fixed Exchange Rate & $0.73 \%$ & $-0.32 \%$ & $-0.77 \%$ & $0.24 \%$ & $0.13 \%$ & $-0.09 \%$ \\
\hline \multirow{2}{*}{0.6} & Exchange Rate Smoothing & $0.11 \%$ & $-0.03 \%$ & $-0.07 \%$ & $0.01 \%$ & $0.04 \%$ & $-0.01 \%$ \\
\hline & Fixed Exchange Rate & $0.39 \%$ & $-0.12 \%$ & $-0.24 \%$ & $0.05 \%$ & $0.14 \%$ & $-0.06 \%$ \\
\hline \multirow{2}{*}{0.7} & Exchange Rate Smoothing & $0.08 \%$ & $-0.01 \%$ & $-0.02 \%$ & $0.00 \%$ & $0.04 \%$ & $-0.01 \%$ \\
\hline & Fixed Exchange Rate & $0.26 \%$ & $-0.06 \%$ & $-0.05 \%$ & $0.00 \%$ & $0.13 \%$ & $-0.04 \%$ \\
\hline \multicolumn{8}{|c|}{ B. Relative Size of Tradable Goods Sector (baseline: $b=0.6$ ) } \\
\hline \multirow{2}{*}{0.5} & Exchange Rate Smoothing & $0.16 \%$ & $-0.03 \%$ & $-0.05 \%$ & $0.00 \%$ & $0.06 \%$ & $-0.02 \%$ \\
\hline & Fixed Exchange Rate & $0.60 \%$ & $-0.18 \%$ & $-0.18 \%$ & $0.02 \%$ & $0.21 \%$ & $-0.10 \%$ \\
\hline \multirow{2}{*}{0.6} & Exchange Rate Smoothing & $0.11 \%$ & $-0.03 \%$ & $-0.07 \%$ & $0.01 \%$ & $0.04 \%$ & $-0.01 \%$ \\
\hline & Fixed Exchange Rate & $0.39 \%$ & $-0.12 \%$ & $-0.24 \%$ & $0.05 \%$ & $0.14 \%$ & $-0.06 \%$ \\
\hline \multirow{2}{*}{0.7} & Exchange Rate Smoothing & $0.07 \%$ & $-0.02 \%$ & $-0.08 \%$ & $0.02 \%$ & $0.03 \%$ & $0.00 \%$ \\
\hline & Fixed Exchange Rate & $0.23 \%$ & $-0.08 \%$ & $-0.26 \%$ & $0.07 \%$ & $0.08 \%$ & $-0.02 \%$ \\
\hline \multicolumn{8}{|c|}{ C. Frisch Elasticity of Labor Supply (baseline: $\psi=1.5$ ) } \\
\hline \multirow{2}{*}{1.0} & Exchange Rate Smoothing & $0.15 \%$ & $-0.03 \%$ & $-0.10 \%$ & $0.02 \%$ & $0.05 \%$ & $-0.01 \%$ \\
\hline & Fixed Exchange Rate & $0.54 \%$ & $-0.16 \%$ & $-0.36 \%$ & $0.08 \%$ & $0.18 \%$ & $-0.06 \%$ \\
\hline \multirow{2}{*}{1.5} & Exchange Rate Smoothing & $0.11 \%$ & $-0.03 \%$ & $-0.07 \%$ & $0.01 \%$ & $0.04 \%$ & $-0.01 \%$ \\
\hline & Fixed Exchange Rate & $0.39 \%$ & $-0.12 \%$ & $-0.24 \%$ & $0.05 \%$ & $0.14 \%$ & $-0.06 \%$ \\
\hline \multirow{2}{*}{2.0} & Exchange Rate Smoothing & $0.09 \%$ & $-0.02 \%$ & $-0.05 \%$ & $0.01 \%$ & $0.03 \%$ & $-0.01 \%$ \\
\hline & Fixed Exchange Rate & $0.31 \%$ & $-0.11 \%$ & $-0.18 \%$ & $0.04 \%$ & $0.11 \%$ & $-0.05 \%$ \\
\hline
\end{tabular}

Notes: This table shows the short-run consumption gains (or losses) and long-run welfare gains from two policy rules-exchange rate smoothing and a fixed exchange rate-relative to a pure inflation targeting rule under different parameter values. The numbers are expressed in percent of cumulative consumption gains/losses over the short run (16 quarters) or percentage points of permanent consumption gains/losses relative to the baseline policy rule in the long run. "T households" refers to households working in the tradable goods sector; "NT households" refers to households working in the nontradable goods sector. 
Table 4. Short-run and Long-run Effects of Alternative Policy Experiments

\begin{tabular}{|c|c|c|c|c|c|c|}
\hline \multirow{2}{*}{ Scenario } & \multicolumn{2}{|c|}{ T Households } & \multicolumn{2}{|c|}{ NT Households } & \multicolumn{2}{|c|}{ Aggregate } \\
\hline & Short-run & Long-run & Short-run & Long-run & Short-run & Long-run \\
\hline \multicolumn{7}{|c|}{ A. Real Exchange Rate Management } \\
\hline Nominal Exchange Rate & $0.11 \%$ & $-0.03 \%$ & $-0.07 \%$ & $0.01 \%$ & $0.04 \%$ & $-0.01 \%$ \\
\hline Real Exchange Rate & $0.10 \%$ & $-0.03 \%$ & $-0.07 \%$ & $0.01 \%$ & $0.04 \%$ & $-0.01 \%$ \\
\hline \multicolumn{7}{|l|}{ B. Capital Controls } \\
\hline Exchange Rate Smoothing & $0.19 \%$ & $-0.09 \%$ & $-0.08 \%$ & $0.04 \%$ & $0.09 \%$ & $-0.04 \%$ \\
\hline Fixed Exchange Rate & $0.97 \%$ & $-0.55 \%$ & $-0.38 \%$ & $0.22 \%$ & $0.43 \%$ & $-0.24 \%$ \\
\hline \multicolumn{7}{|l|}{ C. Fiscal Policy } \\
\hline Tax on Nontradable Goods & $0.36 \%$ & $0.00 \%$ & $-0.59 \%$ & $0.00 \%$ & $-0.03 \%$ & $0.00 \%$ \\
\hline Subsidy on Nontradable Goods & $-0.37 \%$ & $0.00 \%$ & $0.60 \%$ & $0.00 \%$ & $0.02 \%$ & $0.00 \%$ \\
\hline \multicolumn{7}{|l|}{ D. Flexible Inflation Targeting } \\
\hline Exchange Rate Smoothing & $0.25 \%$ & $-0.01 \%$ & $-0.16 \%$ & $0.01 \%$ & $0.09 \%$ & $0.00 \%$ \\
\hline Fixed Exchange Rate & $0.78 \%$ & $-0.16 \%$ & $-0.48 \%$ & $0.06 \%$ & $0.28 \%$ & $-0.07 \%$ \\
\hline
\end{tabular}

Notes: This table shows the short-run consumption gains (or losses) and long-run welfare gains from two policy rules-exchange rate smoothing and a fixed exchange rate-relative to an inflation targeting rule under alternative policy experiments. Panel A compares the effects of nominal and real exchange rate targeting relative to pure inflation targeting. For the results in Panel B, capital controls are imposed regardless of the policy regime. In Panel $\mathrm{C}$, the monetary policy rule is inflation targeting in the baseline and alternative scenarios. The latter two scenarios involve a 3 percent tax or subsidy, respectively, on nontradable goods. In Panel D, the baseline (inflation targeting) and exchange rate smoothing rules include an output gap term. The numbers are expressed in percent of cumulative consumption gains/losses over the short run (16 quarters) or percentage points of permanent consumption gains/losses relative to the baseline policy rule in the long run. "T households" refers to households working in the tradable goods sector; "NT households" refers to households working in the nontradable goods sector. 
Table 5. Short-run and Long-run Effects under Alternative Shocks

\begin{tabular}{|c|c|c|c|c|c|c|}
\hline \multirow{2}{*}{ Scenario } & \multicolumn{2}{|c|}{ T Households } & \multicolumn{2}{|c|}{ NT Households } & \multicolumn{2}{|c|}{ Aggregate } \\
\hline & Short-run & Long-run & Short-run & Long-run & Short-run & Long-run \\
\hline \multicolumn{7}{|c|}{ A. Productivity Shocks in the Nontradable Goods Sector } \\
\hline Nominal Exchange Rate & $-0.10 \%$ & $-0.04 \%$ & $0.07 \%$ & $0.02 \%$ & $-0.04 \%$ & $-0.02 \%$ \\
\hline Real Exchange Rate & $-0.34 \%$ & $-0.16 \%$ & $0.22 \%$ & $0.06 \%$ & $-0.12 \%$ & $-0.07 \%$ \\
\hline \multicolumn{7}{|l|}{ B. Terms of Trade Shocks } \\
\hline Exchange Rate Smoothing & $0.01 \%$ & $0.01 \%$ & $-0.01 \%$ & $-0.01 \%$ & $0.00 \%$ & $0.00 \%$ \\
\hline Fixed Exchange Rate & $0.11 \%$ & $0.02 \%$ & $-0.07 \%$ & $-0.01 \%$ & $0.04 \%$ & $0.01 \%$ \\
\hline \multicolumn{7}{|c|}{ C. Foreign Interest Rate Shocks } \\
\hline Exchange Rate Smoothing & $-0.01 \%$ & $-0.01 \%$ & $0.00 \%$ & $0.00 \%$ & $0.00 \%$ & $0.00 \%$ \\
\hline Fixed Exchange Rate & $-0.46 \%$ & $-0.09 \%$ & $0.27 \%$ & $0.04 \%$ & $-0.06 \%$ & $-0.04 \%$ \\
\hline
\end{tabular}

Notes: This table shows the short-run consumption gains (or losses) and long-run welfare gains from two policy rules-exchange rate smoothing and a fixed exchange rate-relative to a pure inflation targeting rule when the home economy faces different types of shocks. The numbers are expressed in percent of cumulative consumption gains/losses over the short run (16 quarters) or percentage points of permanent consumption gains/losses relative to the baseline policy rule in the long run. "T households" refers to households working in the tradable goods sector; "NT households" refers to households working in the nontradable goods sector. 
Figure 1. Impulse Responses to a Positive Productivity Shock in the Tradable Goods Sector
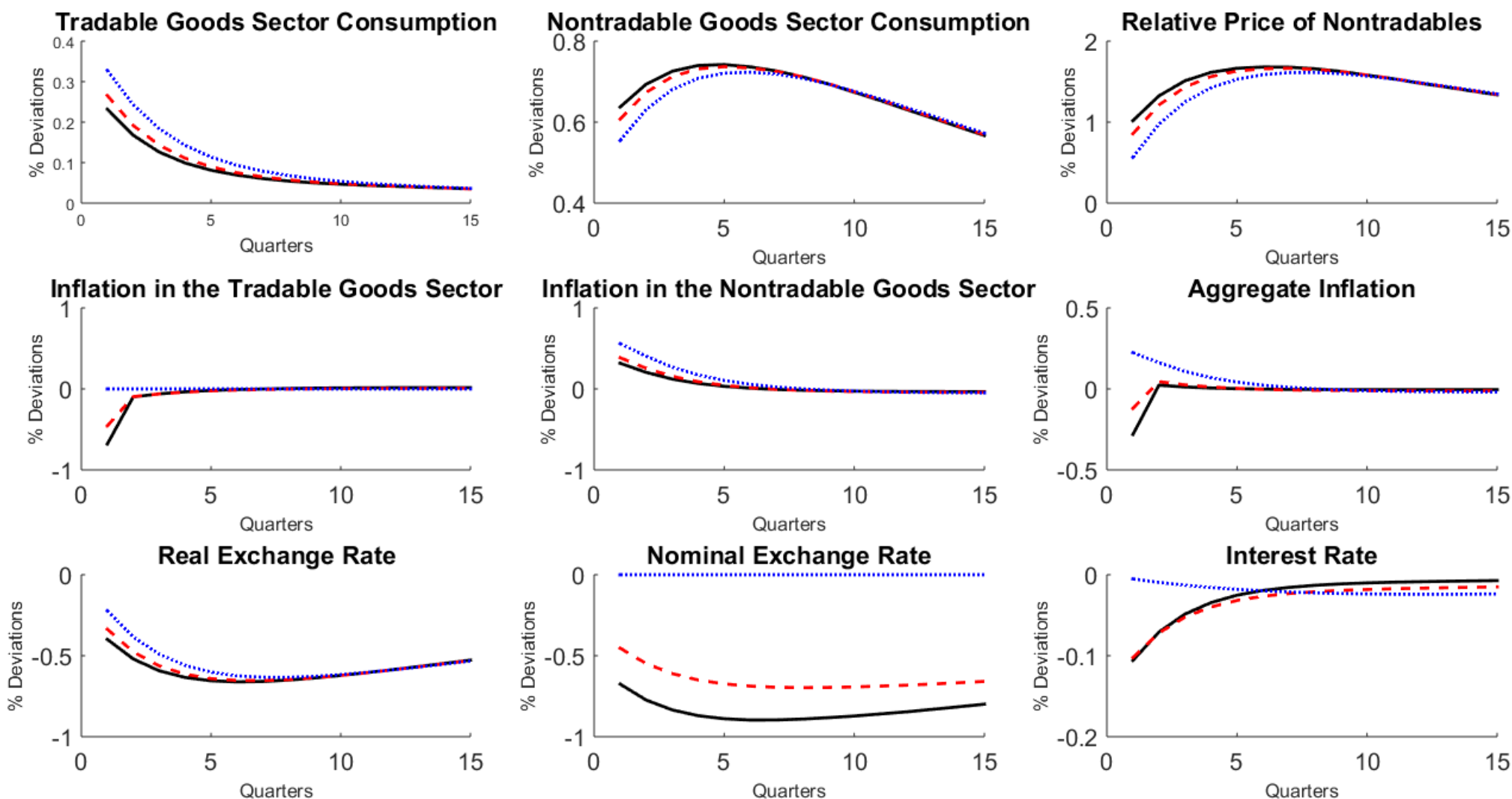

—Baseline Inflation Targeting - - - Exchange Rate Smoothing ……… Fixed Exchange Rate

Notes: This figure shows the responses of different variables to a one standard deviation productivity shock to the home economy's tradable goods sector. Three monetary policy rules are considered. The black solid lines are impulse responses under a pure inflation targeting rule, the red dashed lines represent impulse responses under an exchange rate smoothing rule, and the blue dotted lines show impulse responses under a fixed exchange rate regime. The responses are all expressed as percentage deviations from the steady state values of the corresponding variables. A decline in the exchange rate (both nominal and real) indicates appreciation. 
Figure 2. Impulse Responses to a Positive Productivity Shock in the Tradable Goods Sector (with Capital Controls)
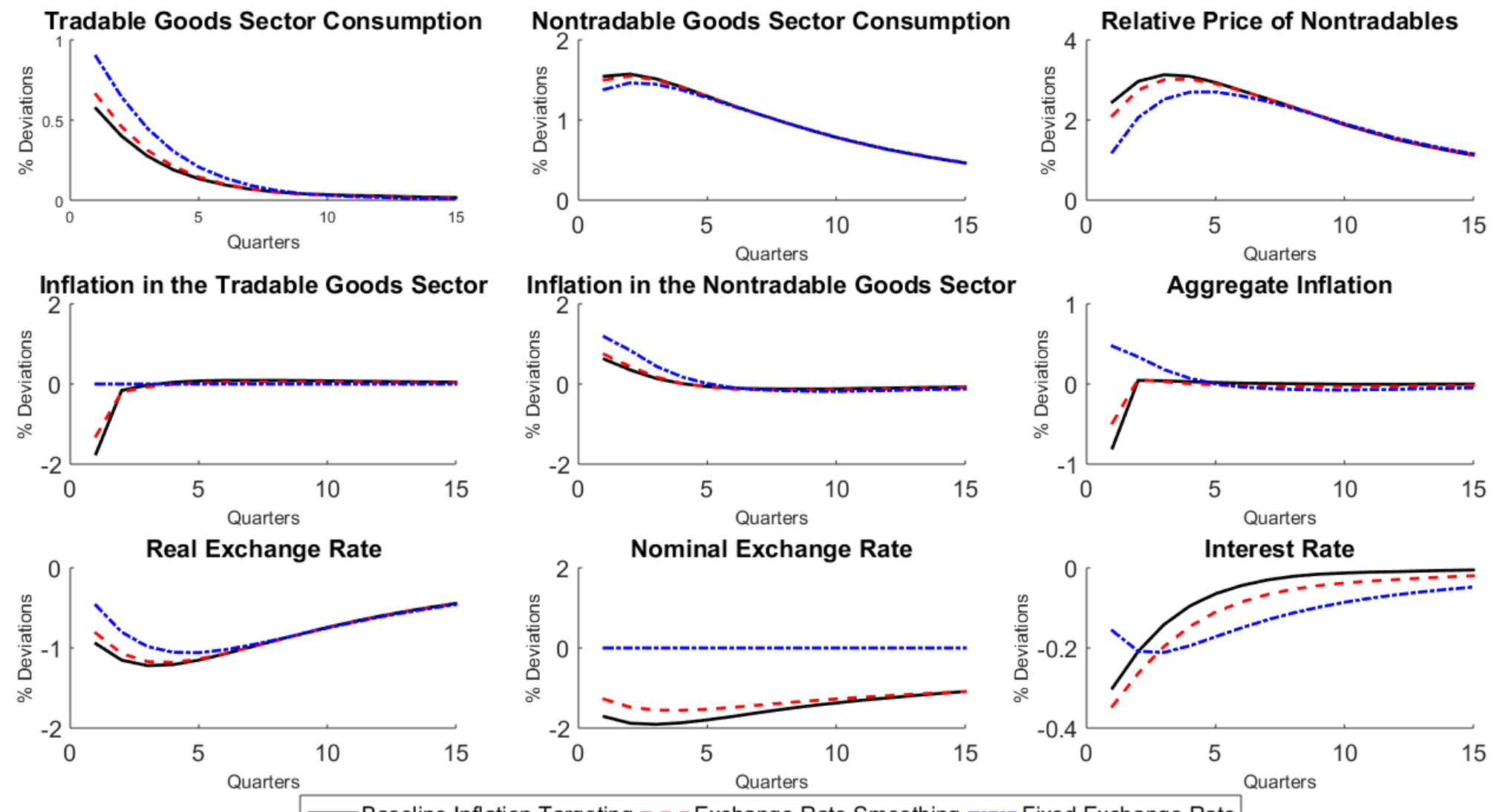

Notes: This figure shows the responses of different variables to a one standard deviation productivity shock to the home economy's tradable goods sector. Capital controls are imposed regardless of the policy regime. Three monetary policy rules are considered. The black solid lines are impulse responses under a pure inflation targeting rule, the red dashed lines represent impulse responses under an exchange rate smoothing rule, and the blue dotted lines show impulse responses under a fixed exchange rate regime. The responses are all expressed as percentage deviations from the steady state values of the corresponding variables. A decline in the exchange rate (both nominal and real) indicates appreciation. 


\section{Appendix I. Equilibrium Conditions of the Baseline}

\section{Model}

This appendix lists the complete system of equations that characterizes the competitive equilibrium under the baseline model, which consists of 28 endogenous variables $\left\{c_{t}^{T}, c_{t}^{N}, c_{t}\right.$, $b_{t}^{*}, w_{T, t}, w_{N, t}, L_{t}^{T}, L_{t}^{N}, Y_{t}, Y_{N, t}, Y_{H, t}, G_{t}, F_{t}, \nu_{t}, R_{t}, \pi_{t}, x_{T, t}, x_{N, t}, x_{F, t}, x_{H, t}, x_{t}, q_{t}^{e}, e_{t}, \pi_{N, t}$ $\left.A_{H, t}, A_{N, t}, S_{t}, R_{t}^{*}\right\}$ and 28 equations.

\section{Household Decisions}

Tradable goods sector households' budget constraints:

$$
C_{t}^{T}+q_{t}^{e} b_{t}^{*}+\frac{\psi_{b}}{2} b_{t}^{* 2}=R_{t-1}^{*} q_{t}^{e} b_{t-1}^{*}+w_{T, t} L_{t}^{T}
$$

Nontradable goods sector households' budget constraints:

$$
(1-\lambda) C_{t}^{N}=x_{N, t} Y_{N, t}
$$

Tradable goods sector households' intertemporal Euler equation from domestic bonds holding:

$$
C_{t}^{T^{-\sigma}}=\beta E_{t}\left(\frac{R_{t}}{\pi_{t+1}} C_{t+1}^{T}{ }^{-\sigma}\right)
$$

Tradable goods sector households' intertemporal Euler equation from foreign bonds holding:

$$
C_{t}^{T^{-\sigma}}=\beta E_{t}\left(\frac{R_{t}^{*}}{\left(1+\psi_{b} b_{t}^{*}\right)} \frac{q_{t+1}^{e}}{q_{t}^{e}} C_{t+1}^{T}{ }^{-\sigma}\right)
$$

Tradable goods sector households' optimal labor supply decision:

$$
w_{T, t}=\phi_{T} C_{t}^{T^{\sigma}} L_{t}^{T^{\psi}}
$$


Nontradable goods sector households' optimal labor supply decision:

$$
w_{N, t}=\phi_{N} C_{t}^{N^{\sigma}} L_{t}^{N \psi}
$$

\section{Firm Production}

Cost minimization for firms in the tradable goods sector:

$$
w_{T, t}=x_{H, t} A_{H, t}
$$

Output in the tradable goods sector is given by:

$$
Y_{H, t}=\lambda A_{H, t} L_{t}^{T}
$$

Optimal price-setting in the sticky price sector is given by:

$$
\left(\frac{1-\theta \pi_{N, t}^{\varepsilon-1}}{1-\theta}\right)^{\frac{1}{1-\varepsilon}}=\frac{G_{t}}{F_{t}}
$$

The recursive formulation of the numerator $G_{t}$ :

$$
G_{t}=\frac{\varepsilon}{\varepsilon-1} C_{t}^{N^{-\sigma}} Y_{N, t} \frac{w_{N, t}}{A_{N, t}}+\beta \theta E_{t} \pi_{N, t+1}^{\varepsilon} G_{t+1}
$$

The recursive formulation of the denominator $F_{t}$ :

$$
F_{t}=x_{n, t} C_{t}^{N^{-\sigma}} Y_{N, t}+\beta \theta E_{t} \pi_{N, t+1}^{\varepsilon-1} F_{t+1}
$$

The dynamics of price dispersion is given by:

$$
\nu_{t}=(1-\theta)\left(\frac{1-\theta \pi_{N, t}^{\varepsilon-1}}{1-\theta}\right)^{\frac{\varepsilon}{\varepsilon-1}}+\theta \pi_{N, t} \nu_{t-1}
$$


Output in the nontradable goods sector is:

$$
\nu_{t} Y_{N, t}=(1-\lambda) A_{N, t} L_{t}^{N}
$$

\section{Aggregate Economy}

The definition of aggregate consumption is given by:

$$
C_{t}=\lambda C_{t}^{T}+(1-\lambda) C_{t}^{N}
$$

The definition of aggregate output is given by:

$$
Y_{t}=x_{H, t} Y_{H, t}+x_{N, t} Y_{N, t}
$$

The market clearing condition for nontradable goods is given by:

$$
(1-b) x_{N, t}^{-\xi} C_{t}=Y_{N, t}
$$

\section{Price, Inflation and Monetary Policy}

Nontradable goods price index and relative prices:

$$
x_{N, t}=x_{N, t-1} \frac{\pi_{N, t}}{\pi_{t}}
$$

Home-produced tradable goods price dynamics:

$$
x_{H, t}=x_{H, t-1} \frac{q_{t}^{e}}{q_{t-1}^{e}} \frac{s_{t}}{s_{t-1}}
$$


Foreign-produced tradable goods price dynamics:

$$
x_{F, t}=x_{F, t-1} \frac{q_{t}^{e}}{q_{t-1}^{e}}
$$

Price index in the Tradable goods sector is given by:

$$
x_{T, t}=x_{F, t}\left[a s_{t}^{1-\eta}+(1-a)\right]^{\frac{1}{1-\eta}}
$$

Aggregate price index and relative prices:

$$
1=\left[b x_{T, t}^{1-\xi}+(1-b) x_{N, t}^{1-\xi}\right]^{\frac{1}{1-\xi}}
$$

The definition of the relative price:

$$
x_{t}=\frac{x_{N, t}}{x_{H, t}}
$$

The definition of the real exchange rate:

$$
\frac{q_{t}^{e}}{q_{t-1}^{e}}=\frac{e_{t}}{e_{t-1} \pi_{t}}
$$

Monetary policy rule (baseline model):

$$
\log \left(\frac{R_{t}}{\bar{R}}\right)=\rho \log \left(\frac{R_{t-1}}{\bar{R}}\right)+(1-\rho)\left[\phi_{\pi} \log \left(\frac{\pi_{t}}{\bar{\pi}}\right)+\phi_{e} \log \left(\frac{e_{t}}{e_{t-1}}\right)\right]
$$

\section{Shocks}

Productivity shock in the tradable goods sector:

$$
\log \left(\frac{A_{H, t}}{\bar{A}_{H}}\right)=\rho_{a}^{H} \log \left(\frac{A_{H, t-1}}{\bar{A}_{H}}\right)+\varepsilon_{t}^{H}
$$


Productivity shock in the nontradable goods sector:

$$
\log \left(\frac{A_{N, t}}{\bar{A}_{N}}\right)=\rho_{a}^{N} \log \left(\frac{A_{N, t-1}}{\bar{A}_{N}}\right)+\varepsilon_{t}^{N}
$$

Terms of trade shock in the tradable goods sector:

$$
\log \left(\frac{S_{t}}{\bar{S}}\right)=\rho_{s} \log \left(\frac{S_{t-1}}{\bar{S}}\right)+\varepsilon_{t}^{\sigma}
$$

Foreign interest shock:

$$
\log \left(\frac{R_{t}^{*}}{\bar{R}^{*}}\right)=\rho_{r} \log \left(\frac{R_{t-1}^{*}}{\bar{R}^{*}}\right)+\varepsilon_{t}^{r}
$$

